\title{
Konfrontasi Malaysia Indonesia (Malay Version)
}

Iqbal U*

History Programme, Faculty of Social Sciences and Humanities, National University of Malaysia, Malaysia

${ }^{*}$ Corresponding author: Iqbal U, History Programme, Faculty of Social Sciences and Humanities, National University of Malaysia, UKM 43650, Bangi Selangor, Malaysia, Tel: 60389215555; E-mail: uqbah@siswa.ukm.edu.my

Received date: November 26, 2015; Accepted date: December 15, 2015; Published date: December 23, 2015

Copyright: (c) 2015 Iqbal U. This is an open-access article distributed under the terms of the Creative Commons Attribution License, which permits unrestricted use, distribution, and reproduction in any medium, provided the original author and source are credited.

\section{Commentary}

Indonesia occupies a very special place in the foreign policy of Malaysia. Even before independence, the people of Malaya joined the volunteer team that helped Indonesia's struggle for independence from the Dutch. Therefore Tunku Abdul Rahman, the first Prime Minister of the Federation of Malaya has sent his best friend, Senu Abdul Rahman as the Federation of Malaya's first ambassador to Indonesia. In 1959, Malaya signed the Treaty of Friendship and Culture with Indonesia with a view to strengthen the relations between the two allied countries. However, Malaysia friendly relations with Indonesia are inconsistent. Personal conflicts and differences of understanding with regard to the question of international relations among the factor relations between the two countries get cool.

Confrontation is the biggest challenge ever faced by Malaysia when it was young and inexperienced in managing conflict. The confrontation broke out between Malaysia and Indonesia as a result of the agreement between with Tunku Abdul Rahman and MacMillan to establish Malaysia comprising the Federation of Malaya, Singapore, Brunei, Sarawak and Sabah (North Borneo) on August 31, 1963. Based on the experience of the 1950s, Indonesia considers that Malaysia established is a trick of the Western powers to isolate and besiege Indonesia. Therefore, the establishment of Malaysia launched protests and confrontations. Philippines is also against the establishment of Malaysia, its partner in the Association of South Africa (ASA). Philippines are against the inclusion of Sabah in Malaysia on the grounds that it was its territory.

Protest and pressure from neighboring countries not weaken Tunku Abdul Rahman to fight the idea of Malaysia. For Tunku Abdul Rahman, only through Malaysia idea can help him to liberate the territories in Borneo from British colonial rule. Tunku Abdul Rahman realized that the provinces cannot afford to be independent and run the risk of being swallowed by its greater neighbors. Philippines claim North Borneo, while Indonesia is also keen to expand its sphere of influence in terms of 'Indonesia Raya'. Initially British do not agree Borneo territories joined in Malaysia. However, the British had to give in when it encounters a problem in Singapore. Alarmed by the possibility of PAP losing in the general election and the possibility of the Socialist Party ruling, the British have no choice but to include Singapore with the Federation of Malaya.

Although the verdict of the people in Sabah and Sarawak to be confirmed by United Nations Secretary-General, the Philippines and Indonesia choose not to accept it for various reasons. Indonesia act more aggressively. Movement invasion of the territory in Malaysia especially in Sabah and Sarawak have been further improved. Friendly countries like the United States, Thailand and Japan try to resolve the crisis through negotiations but fail miserably. The talks in Bangkok and Tokyo in 1964 deadlocked. In the face of threats of Indonesia, Malaysia already has the support of friendly countries in the ANZAM alliance namely Britain, Australia and New Zealand. Malaysia and its allies have planned a variety of military operations for the oppressed retaliation if Indonesia launched a massive attack against Malaysia. At the same time, Malaysia has also spread to the international community about Indonesia aggressiveness by complaining to the United Nations Security Council and the international forum.

While Malaysia is facing the threat of Indonesia, a crisis broke out between Tunku Abdul Rahman and Lee Kuan Yew led to the separation of Singapore from Malaysia on 9 August 1965. The separation of Singapore from Malaysia was disappointing British. The separation affects the original goal of the formation of Malaysia, which is to defend and protect its base in Singapore and Borneo territories from the threat of foreign powers. The incident also led the British government to review its policy towards Indonesia. However, Indonesia has failed to exploit the issue because of its domestic political crisis namely the Gestapu. Singapore partition does not affect the integrity of Malaysia, on the contrary reinforce its position and free itself from the burden of politics. Tun Abdul Razak considers the presence of Singapore in Malaysia is like a thorn in the flesh.

On 30 September 1965, the army of pro-Soekarno with the strong support of the Communist Party of Indonesia tried to take power under the pretext of protecting the President from the General Assembly threats. General Suharto, who deemed to be an antiCommunist, had foiled the coup attempt. The emergence of General Suharto was welcomed by Malaysia and Britain. The change has relieved the confrontation tempo and open negotiations to end the confrontation between Malaysia and Indonesia.

Wisdom of the country under the leadership of Tunku Abdul Rahman has managed to save the country from the scourge of war with cognate nation. In terms of the role and bitter national leadership under Tunku Abdul Rahman, Tun Abdul Razak and his senior officers, especially Tan Sri Ghazali Shafie as Permanent Secretary of the Foreign Ministry in handling the confrontation should be recorded for future generations. The outcome of brilliant negotiation between Tun Abdul Razak and Tan Sri Ghazali Shafie with Adam Malik, the Indonesian Foreign Minister, and General Ali Moetopo in Bangkok and Jakarta in early 1966, on 11 August 1966, Malaysia-Indonesia Confrontation has ended.

This study is based on official sources of the British government kept in the Public Record Office, Kew, England. Among the records of the British government referred are records of the Cabinet (CAB), Prime Minister's Office (PREM), the Foreign Office (FO), the Commonwealth Relations Office (CRO) and the Office of Defense (DEF). It is hoped that this study will be beneficial to international and history student, politicians and government officials, especially those interested in the methods of conflict management and decision makers. 